\title{
Design, Building and Performance Evaluation of a Mixed-Mode Solar Dryer for Agricultural Products
}

\author{
MAHMOUD MOHAMED EL-GHOBASHY EL-HAGAR \\ Mechanical Engineering Department \\ Industrial Education College \\ Beni-Suef University \\ EGYPT
}

\begin{abstract}
This research work presents the detailed explana tion of the design, construction and perform ance evaluation of mixed-mode solar agricu ltural products dryer. The experimental set up used for testing the performance of the mixed-mode solar agricultural $p$ roducts dryer and determ ining the influence of vari ous drying methods on the drying behaviour of agricultural products. Evaluation of the dryer was centered on the moisture content reduction, temperatures and relative humidities variations. $1680 \mathrm{~g}$ of freshly potato slides were used for evaluation.

The test results gave that the temperatures inside the dryer cabinet and the solar collector were much higher than the ambient temperature during most hours of the daylight. The temperature inside the solar collector was up to $27^{\circ} \mathrm{C}$ approximately higher than the ambient temperature. The temperature inside the drying cabinet was up to $22 \mathrm{C}$ approximately higher than the ambient temperature for about three hours immediately after $12.00 \mathrm{~h}$ (noon). The relative humidity in the solar collector an d drying cabinet were lower than the am bient air relative humidity, with the am bient air recording the highest re lative humidity at each reading followed by the drying cabinet and finally by the solar collector. Because of the decreased relative humidity inside the dry er, all the time, the temperature inside the dryer was high which is sufficient enough to dry the potato at an early time.

Based on the results obtained during $t$ he test, temperature above $65^{\circ} \mathrm{C}$ was recorded inside the dry ing cabinet. This high temperature in the drying cabinet causes $419 \mathrm{~g}$ of m oisture to be rem oved on the first day, 257 $\mathrm{g}$ on the second day, $191 \mathrm{~g}$ on the third day, $136 \mathrm{~g}$ on the four th day and finally $108 \mathrm{~g}$ on the fifth day. At the end of the five day s of drying process, the mass of $1680 \mathrm{~g}$ of potato was reduced to $569 \mathrm{~g}$. Total amount of moisture removed was $1111 \mathrm{~g}$ and total moisture loss was $66.1 \%$, which is the required amount of moisture to be removed for safe dry ing of freshly potato slides. The moisture content of the freshly potato slides was $24.9 \%$ at the end of drying for the first day at about 5:00 pm, $20.4 \%$ at the end of dry ing for the second day, $19 \%$ at the end of drying for the third day, $16.7 \%$ at the end of drying for the fourth day and finally $15.9 \%$ at the end of drying for the fifth day. It was observed that the drying rate increased fro $m$ the end of one day to an other, which shows the earlier and faster removal of moisture from the dried item.
\end{abstract}

Key-Words: - Solar Ener gy, Mixed-Mode Solar D ryer, Solar Collector, Drying Cabinet, Solar Radi ation, Ambient Temperature, Relative Humidity, Moisture Content, \% Moisture Loss, Freshly Potatoes Slides

Received: October 11, 2019. Revised: May 14, 2020. Accepted: May 25, 2020. Published: June 8, 2020.

\section{Introduction}

Agricultural products drying is the most energy consuming process in all process es on the farm. The purpose of drying is to $r$ emove moisture from the agricultural produce so th at it can be processed safely and s tored for increased periods of tim e. Drying is very important process applicable for agricultural and ind ustrial products. Dry ing is the moisture removing process fro $\mathrm{m}$ the products. Drying reduces the bacterial growth in the products. It will helpful for preserving the products for long time. Solar drying is the oldest method of products drying. Open air solar dr ying method is used frequently to dry the agricultural products. But this method has some disadvantages. Therefore to avo id disadvantages it is necess ary to use the other solar

drying methods. Different solar drying methods are direct solar drying, indirect solar drying, and mixed mode solar drying. The device used for $\mathrm{dr}$ ying process with application of solar en ergy called the Solar dryer. Solar dry er are al so classified with mode of ai $r$ circulation to natural and forces convection $[1,2,4]$.

Direct solar drying is the conventional way of drying the products. In this method the products are directly exposed to the s olar radiation and reduce the moisture content to atmospheric air. The air movement is due to density difference.

Indirect solar dry ing or convective solar dry ing is the new technique of $p$ roduct drying. It is very efficient method than the direct type of solar drying. In this method the atmospheric air is heated in flat plate collector or concentrated ty pe solar collector. 
The heating process is either passive or active. This hot air then flow in the cabin where products are stored. Therefore moisture from the product may lost by convection. This method of drying is used to avoid direct exposing to the solar radiation. This method mainly reduces the disadvantages of direct solar drying.

Mixed mode solar dry ing is co mbination of direct and indirect solar dr ying method. Product may dry with both direct exposure to solar radiation and hot air supplier on it. Air may heated in solar energy collector first then pass to the cabinet where products are stored. In this process product may dry according to convective moisture loss. The same cabinet is partially or totally covered with the transparent material to exposure the products to solar radiation.

Drying is an ess ential process in the preservation of agricultural products. Dry ing preserves foods by removing enough moisture from food to prevent decay and spoilage. Drying of foods, the key is to remove moisture as quickly as possible at a temperature that does not seriously affect the flavour, texture and colour of the food. Various drying methods are emplo yed to dry different agricultural products [5-10].

Drying is the reduction of $m$ oisture from the products and is a most important process for preserving agricultural products since it has a great effect on the quality of the dried products. The major objective in drying agricultural products is the reduction of the moisture content to a level which allows safe storage over a $\mathrm{n}$ extended period. Solar dryer is the simple devices used to collect the solar radiations and transfer that radiation in the form of heat energy and this heat energy then transfer to product for drying [3, 11-15].

The objective of this study is to pre sent the detailed explanation of the design, co nstruction of the mixed-mode solar ag ricultural products dryer using locally available materials and to evaluate the performance of this dry er, in which the grains are dried simultaneously by both direct radiatio $n$ through the transparent roof of the cabinet and by the heated air from the solar collector. The experimental set up used for testing the performance of the mixed-mode solar agricultural products dryer and determining the influence of va rious drying methods on the drying behaviour of agricultural products. Evaluation of the dry er was centered on the moisture content reduction and te mperature variations. $1680 \mathrm{~g}$ of freshly potato slides were used for evaluation. Temperatures and relative humidities of the drying cabinet, solar collector and ambient air were taken daily using digital sensors on an hourly basis from 9:00 am to 5:00 pm . Moisture content was taken at the beginning and at the end of each drying days.

\section{Materials and Methods}

The solar dryer considered in this research paper is the m ixed-mode forced convection solar dr yer. The materials used for the construction of the mixed-mode solar dry er are cheap and easily obtainable in the local market. Figure 1 shows the main components of the mixed-mode solar dry er. The solar dr yer consists of the solar collector (air heater), the dr ying cabinet and four drying trays. The flat-plate solar collector is alway $\mathrm{s}$ tilted and oriented in such a way that it receives maximum solar radiation during the desired season of used, therefore, solar collector i $\mathrm{n}$ this resear ch work is oriented facing south and tilted at $17.5{ }^{\circ}$ to the horizontal.

\section{The mixed-mode solar dryer components:}

- Solar collector: The two main components of the solar coll ector are firstly the absorber plate which made from a metal painted black to absorb the i ncident solar radiation an $d$ placed below the cover plate which used to cover the absorber plate, thereby preventing dust and rain from coming in contact with the absorber, it also retards heat from escaping, common materials used for cover plates is a glass. In this research paper, aluminum is chosen because of its quick response in the absorption of solar radiation and secondly the insulation which used to minimize heat loss from the sy stem, it is under the absorber plate, the insula tor must be able to withstand stagnation tem perature, it should be fire resistant and not be damageable by moisture or insects.

- Drying cabinet: The dry ing cabinet is $m$ ade from wood, the material has been chosen since wood is a poor conductor of heat and its smooth surface finish, heat loss by radiation is minimized.

The designed mixed-mode solar dryer with all components are shown in figure $2.1-2.4$. 


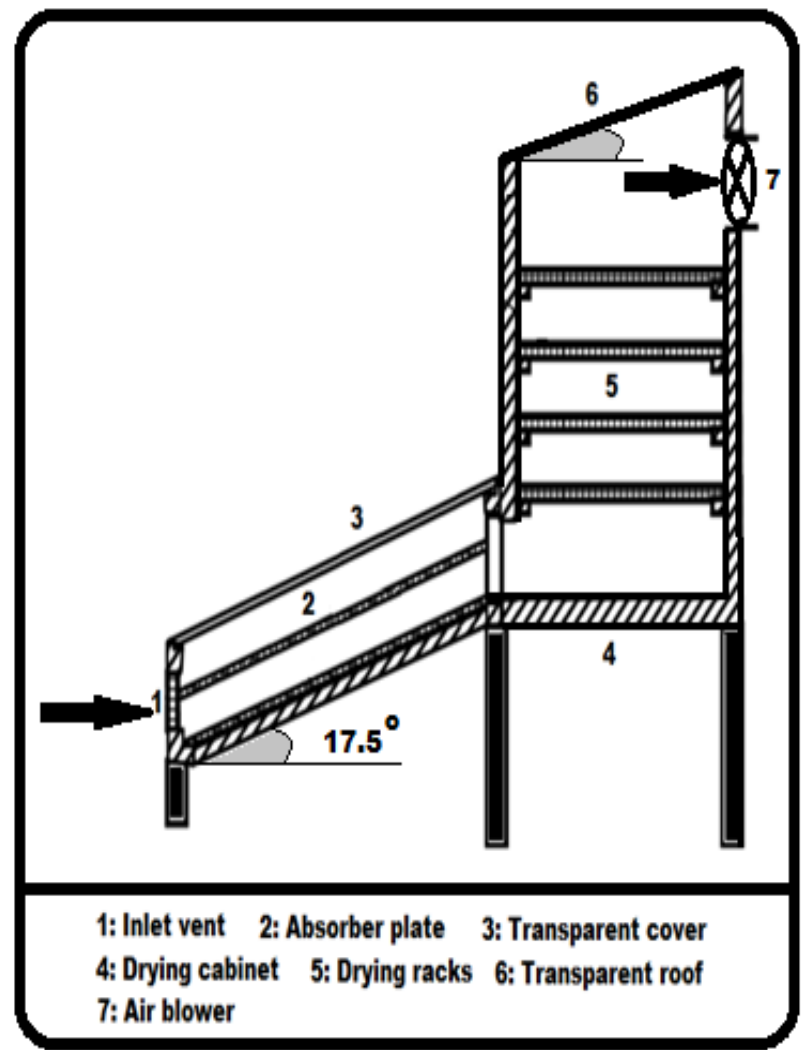

Fig. 1 Main components of the mixed-mode solar agricultural products dryer

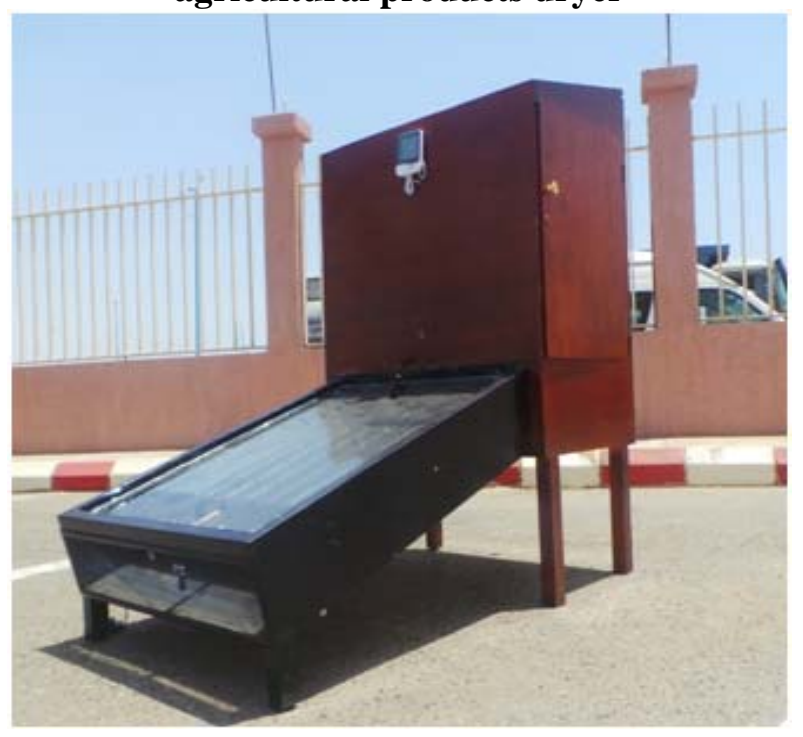

Fig. 2.1 Photo of the designed mixed-mode solar dryer

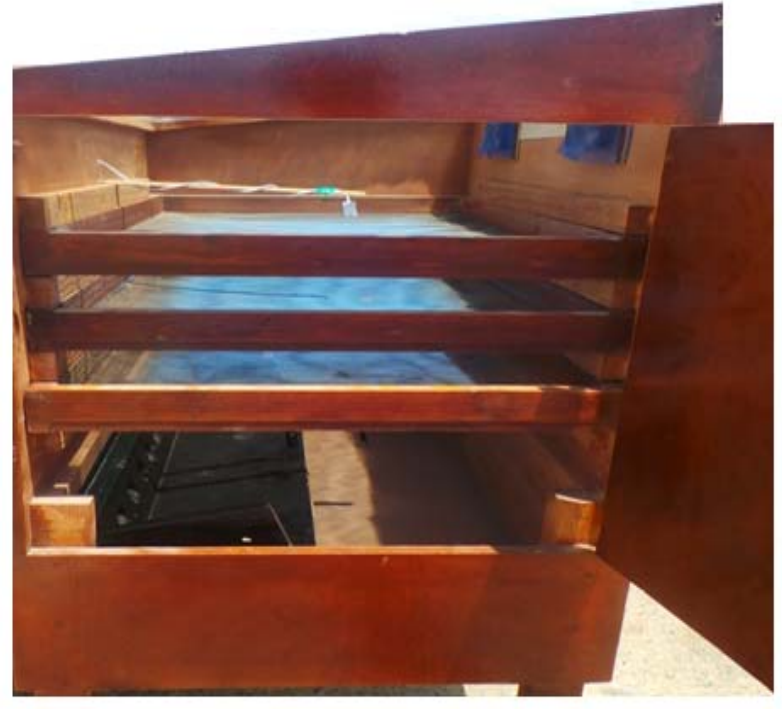

Fig. 2.2 Photo of the designed drying cabinet with its drying racks

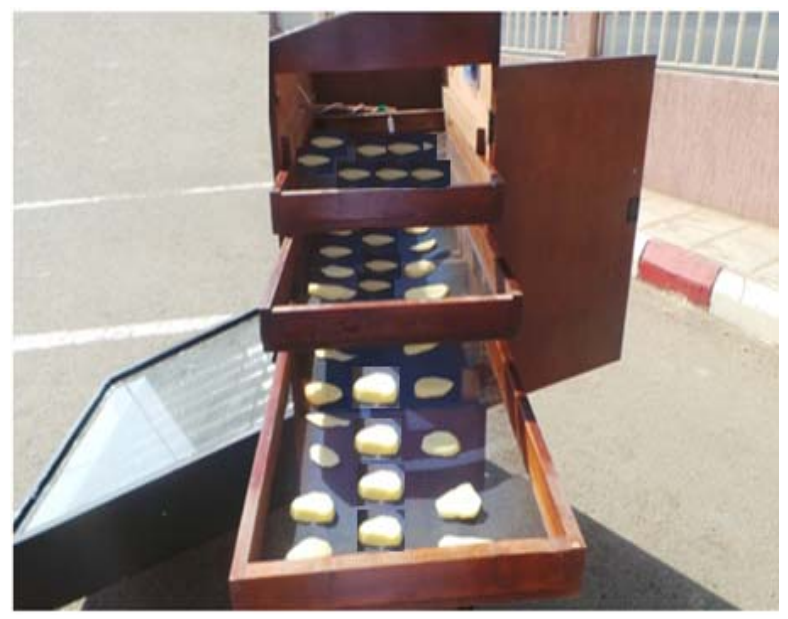

Fig. 2.3 Photo of the designed drying racks with freshly potato slides

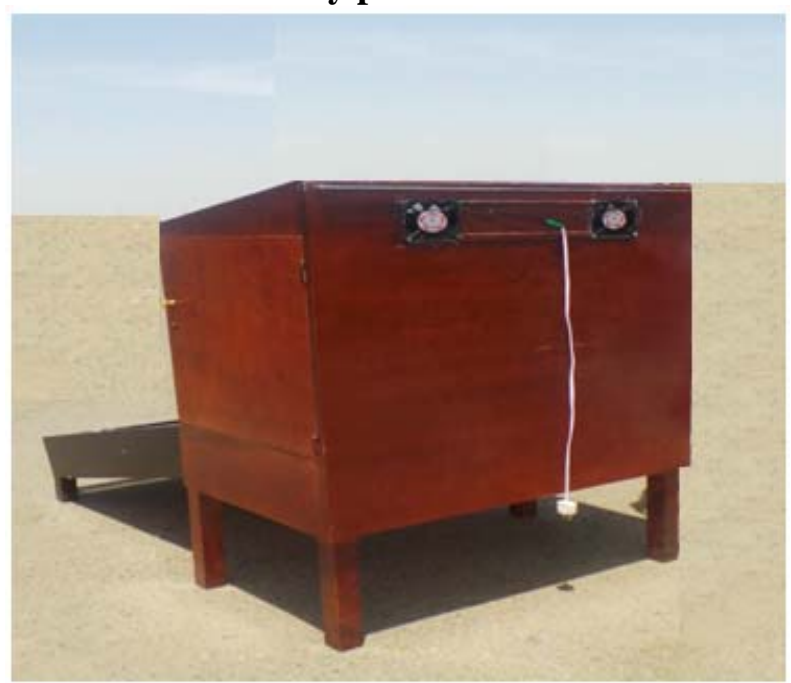

Fig. 2.4 Photo of the designed mixed-mode dryer from the bottom with two air blowers 


\section{Testing}

The testing of the $\mathrm{m}$ ixed-mode solar dryer was done in the month of October for fi ve days starting from 9:00 am to 5:00 $\mathrm{p} \quad \mathrm{m}$. The solar Dry er was placed outside with the collector facing the direction of the sun. The collector has been rigidly fixed to the dryer at an angle approximately $17.5^{\circ}$ to the horizontal to obtain approximately perpendicular beam of sun rays to avoid damage in transit. Slides of freshly potatoes were arranged on the drying bed in a single layer to avoid moisture being trapped in the lower lay er. The dry er cabinet door was closed and seals placed in position. Evaluation of the dryer was centered on the te mperature and relative humidity variations and moisture content reduction . $1680 \mathrm{~g}$ of fr eshly potatoes slides were used for evaluation.

\subsection{Evaluation of the Dryer:}

Evaluation of the dry er was centered on the moisture content reduction and te mperature variations. $1680 \mathrm{~g}$ of freshly potatoes slides were used for evaluation.

\subsection{Temperature:}

Temperatures of the dry ing cabinet, solar collector and am bient air were taken daily using digital sensors on an hourly basis from 9:00 am to 5:00 pm.

\subsection{Relative Humidity:}

Relative humidity may be defined as the ratio of the water vapor densit y (mass per unit volum e) to the saturation water vapor density, usuall $y$ expressed in percent:

$$
\text { Relatlve Humldity }(\mathrm{RH})=\frac{\text { Actual Vapour Density }}{\text { Saturation Vapoud Density }} \times 100
$$

Relative humidity of the drying cabinet, solar collector and am bient air were taken daily using digital sensors on an hourly basis from 9:00 am to 5:00 pm.

\subsection{Moisture content:}

Moisture content was taken at the beginning and at the end of each drying day using the oven dry ing method and calculated using the following equation:

Where:

$$
\text { Molsture content }=\frac{M_{l}-M_{f}}{M_{1}} \times 100
$$

$\mathrm{M}_{\mathrm{i}}=$ Mass of potato slides before drying

$\mathrm{M}_{\mathrm{f}}=$ Mass of potato slides after drying

\section{Results and Discussions}

\subsection{Variation of temperatures with time}

Variations in tem perature were observed as shown in Tables $1-5$ and Figures $3.1-3.5$. Lower temperatures were recorded during the morning and evening hours with the morning hours recording the lowest temperatures. At 9:00 am, the ambient temperature was about $33{ }^{\circ} \mathrm{C}$, while the solar collector recorded about $48{ }^{\circ} \mathrm{C}$ and the solar dry ing cabinet had about $43{ }^{\circ} \mathrm{C}$. At 5:00 pm, the temperatures were about $38{ }^{\circ} \mathrm{C}, 58{ }^{\circ} \mathrm{C}$ and $53{ }^{\circ} \mathrm{C}$ for ambient, solar collector and dry ing cabinets respectively.

It is observed from Tables that, the temperatures in the solar collector and drying cabinet were higher than the a mbient temperatures, with the solar collector recording the highest te mperature at e ach reading followed by the drying cabinet. The highest temperatures were record ed during n oon. At 2:0 0 $\mathrm{pm}$, the ambient temperature was about $44{ }^{\circ} \mathrm{C}$ while the solar col lector recorded $70{ }^{\circ} \mathrm{C}$ and the solar drying cabinet had $65^{\circ} \mathrm{C}$.

\section{Results on $1^{\text {st }}$ October 2015}

\section{Table 1: Variation of temperature with time on} the first day

\begin{tabular}{|c|c|c|c|c|c|c|c|c|c|}
\hline Day 1 & \multicolumn{10}{|c|}{} \\
\hline Time & $\mathbf{9}$ & $\mathbf{1 0}$ & $\mathbf{1 1}$ & $\mathbf{1 2}$ & $\mathbf{1 3}$ & $\mathbf{1 4}$ & $\mathbf{1 5}$ & $\mathbf{1 6}$ & $\mathbf{1 7}$ \\
\hline A.T ( $\mathbf{(}^{\mathbf{} C)}$ & 34 & 37 & 38 & 40 & 42 & 43 & 41 & 39 & 38 \\
\hline C.T ( $\left.{ }^{\mathbf{0}} \mathbf{C}\right)$ & 48 & 51 & 56 & 64 & 67 & 68 & 64 & 60 & 58 \\
\hline $\begin{array}{c}\text { D.C.C } \\
\left({ }^{\mathbf{}} \mathbf{C}\right)\end{array}$ & 43 & 46 & 51 & 59 & 62 & 63 & 59 & 55 & 53 \\
\hline
\end{tabular}

A.T = Ambient Temp., C.T = Collector Temp., D.C.T $=$ Drying Cabinet Temp.

Results on $2^{\text {nd }}$ October 12015

Table 2: Variation of temperature with time on the second day

\begin{tabular}{|c|c|c|c|c|c|c|c|c|c|}
\hline Day 2 & \multicolumn{10}{|c|}{} \\
\hline Time & $\mathbf{9}$ & $\mathbf{1 0}$ & $\mathbf{1 1}$ & $\mathbf{1 2}$ & $\mathbf{1 3}$ & $\mathbf{1 4}$ & $\mathbf{1 5}$ & $\mathbf{1 6}$ & $\mathbf{1 7}$ \\
\hline A.T $\left({ }^{\circ} \mathbf{C}\right)$ & 34 & 38 & 39 & 41 & 43 & 44 & 42 & 40 & 39 \\
\hline C.T $\left({ }^{0} \mathbf{C}\right)$ & 49 & 52 & 57 & 65 & 68 & 69 & 66 & 62 & 59 \\
\hline $\begin{array}{c}\text { D.C.T } \\
\left({ }^{\mathbf{0}} \mathbf{C}\right)\end{array}$ & 44 & 47 & 52 & 60 & 63 & 64 & 61 & 57 & 54 \\
\hline
\end{tabular}

Results on $3^{\text {rd }}$ October 2015

Table 3: Variation of temperature with time on the third day

\begin{tabular}{|c|c|c|c|c|c|c|c|c|c|}
\hline Day 3 & \multicolumn{10}{|c|}{} \\
\hline Time & $\mathbf{9}$ & $\mathbf{1 0}$ & $\mathbf{1 1}$ & $\mathbf{1 2}$ & $\mathbf{1 3}$ & $\mathbf{1 4}$ & $\mathbf{1 5}$ & $\mathbf{1 6}$ & $\mathbf{1 7}$ \\
\hline A.T $\left({ }^{0} \mathbf{C}\right)$ & 33 & 37 & 38 & 40 & 42 & 43 & 41 & 40 & 40 \\
\hline C.T $\left({ }^{0} \mathbf{C}\right)$ & 50 & 53 & 58 & 66 & 69 & 70 & 67 & 63 & 60 \\
\hline $\begin{array}{c}\text { D.C.T } \\
\left({ }^{\circ} \mathbf{C}\right)\end{array}$ & 45 & 48 & 53 & 61 & 64 & 65 & 62 & 58 & 55 \\
\hline
\end{tabular}




\section{Results on $4^{\text {th }}$ October 2015}

Table 4: Variation of temperature with time on the fourth day

\begin{tabular}{|c|c|c|c|c|c|c|c|c|c|}
\hline Day 4 & \multicolumn{10}{|c|}{} \\
\hline Time & $\mathbf{9}$ & $\mathbf{1 0}$ & $\mathbf{1 1}$ & $\mathbf{1 2}$ & $\mathbf{1 3}$ & $\mathbf{1 4}$ & $\mathbf{1 5}$ & $\mathbf{1 6}$ & $\mathbf{1 7}$ \\
\hline A.T ( $\left.\mathbf{(}^{\mathbf{}} \mathbf{C}\right)$ & 37 & 38 & 39 & 40 & 42 & 44 & 43 & 41 & 39 \\
\hline C.T ( $\left.{ }^{\mathbf{0}} \mathbf{C}\right)$ & 52 & 53 & 55 & 64 & 67 & 70 & 66 & 62 & 59 \\
\hline $\begin{array}{c}\text { D.C.T } \\
\left({ }^{\mathbf{}} \mathbf{C}\right)\end{array}$ & 47 & 48 & 50 & 59 & 62 & 65 & 61 & 57 & 54 \\
\hline
\end{tabular}

Results on $5^{\text {th }}$ October 2015

Table 5: Variation of temperature with time on the fifth day

\begin{tabular}{|c|c|c|c|c|c|c|c|c|c|}
\hline Day 5 & \multicolumn{10}{|c|}{$\mathbf{1 0}$} & $\mathbf{1 3}$ & $\mathbf{1 5}$ & $\mathbf{1 7}$ \\
\hline Time & $\mathbf{9}$ & $\mathbf{1 0}$ & $\mathbf{1 1}$ & $\mathbf{1 2}$ & $\mathbf{1 3}$ & $\mathbf{1 4}$ & $\mathbf{1 5}$ & 41 & 40 \\
\hline A.T ( $\left.{ }^{\mathbf{C}} \mathbf{C}\right)$ & 37 & 38 & 39 & 41 & 43 & 44 & 42 & 41 \\
\hline C.T ( $\mathbf{0}$ C) & 51 & 53 & 55 & 65 & 68 & 69 & 65 & 63 & 61 \\
\hline $\begin{array}{c}\text { D.C.T } \\
\text { ('C) }\end{array}$ & 46 & 48 & 50 & 60 & 63 & 64 & 60 & 58 & 56 \\
\hline
\end{tabular}

Figures 3.1 to 3.5 show a typical day results of the hourly variation of the temperatures in the solar collector and the dry ing cabinet compared to the ambient temperature. The dryer is hottest about midday when $t$ he sun is usually overhead. The temperatures inside the dry er cabinet and the solar collector were much higher than the a mbient temperature during most hours of the daylight. The temperature inside the solar collector was up to 27 ${ }^{\circ} \mathrm{C}$ approximately higher than the am bient temperature. The te mperature inside the dry ing cabinet was up to $22{ }^{\circ} \mathrm{C}$ approximately higher than the ambient temperature for about three hours immediately after $12.00 \mathrm{~h}$ (noon).

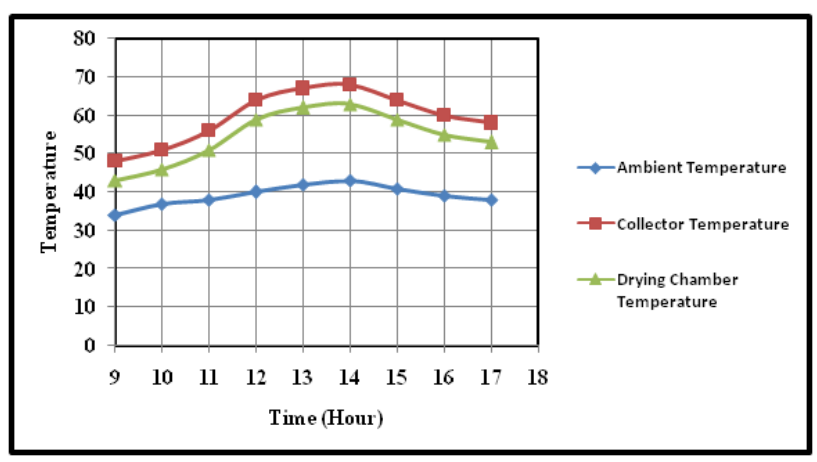

Fig. 3.1 Variation of temperature with time on the first day

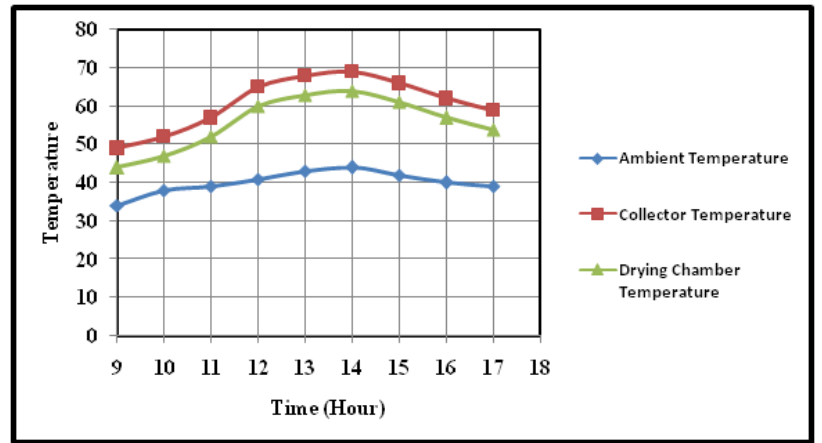

Fig. 3.2 Variation of temperature with time on the second day

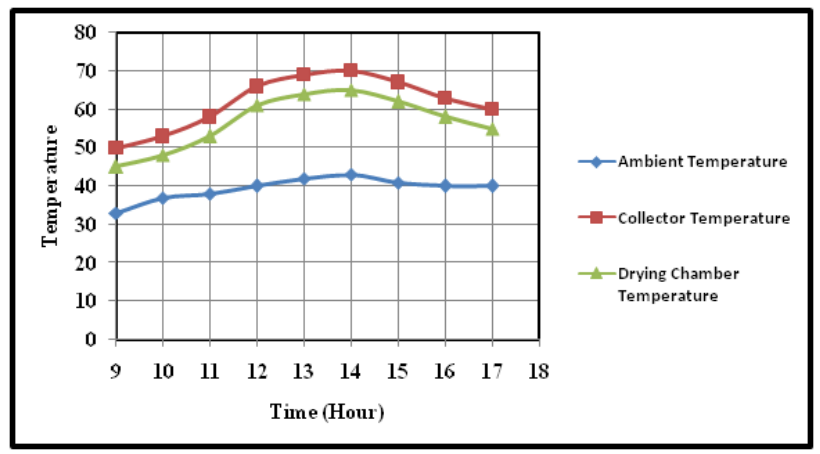

Fig. 3.3 Variation of temperature with time on the third day

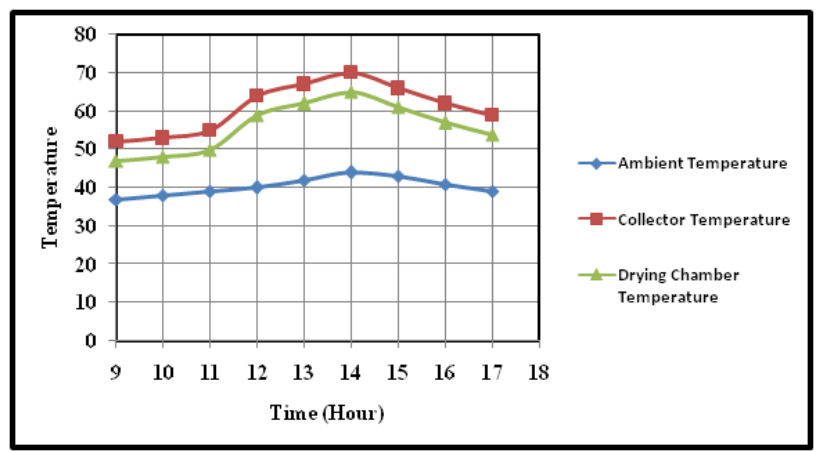

Fig. 3.4 Variation of temperature with time on the fourth day

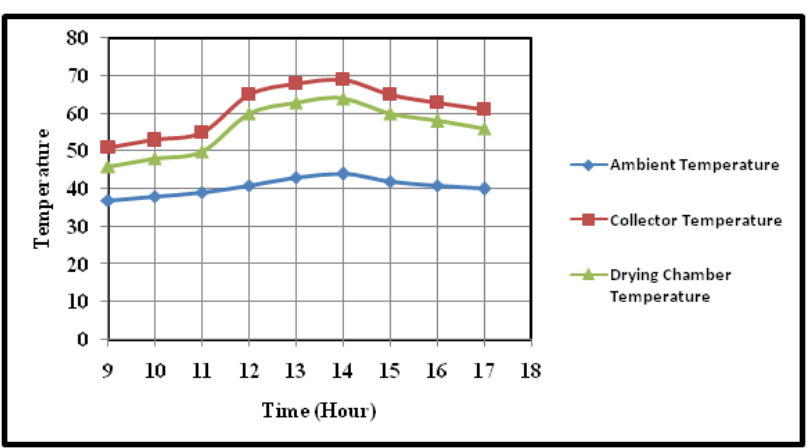

Fig. 3.5 Variation of temperature with time on the fifth day 


\subsection{Variation of relative humidity with time}

Variations in relative humidity were observed as shown in tables $6-10$ and figures $4.1-4.5$. It is observed from tables and figures that, the relative humidity in the solar collector and dry ing cabinet were lower than the am bient air relati ve humidity, with the ambient air recording the highest relative humidity at each reading followed by the dry ing cabinet and finally by the solar collector. Because of the decreased relative humidity inside the dry er, all the time, the te mperature inside the dryer was high which is sufficient enough to $\mathrm{dr} y$ the potato at an early time.

\section{Results on $1^{\text {st }}$ October 2015}

Table 6: Variation of relative humidity with time on the first day

\begin{tabular}{|c|c|c|c|c|c|c|c|c|c|}
\hline Day 1 & \multicolumn{10}{|c|}{1} \\
\hline Time & $\mathbf{9}$ & $\mathbf{1 0}$ & $\mathbf{1 1}$ & $\mathbf{1 2}$ & $\mathbf{1 3}$ & $\mathbf{1 4}$ & $\mathbf{1 5}$ & $\mathbf{1 6}$ & $\mathbf{1 7}$ \\
\hline A.R.H & 66 & 62 & 62 & 61 & 59 & 58 & 59 & 58 & 58 \\
\hline C.R.H & 31 & 27 & 27 & 26 & 24 & 23 & 24 & 23 & 23 \\
\hline D.C.R.H & 39 & 35 & 35 & 34 & 32 & 31 & 32 & 31 & 31 \\
\hline
\end{tabular}

A.R.H=Ambient Relative Humidity, C.R.H=Collector Relative Humidity, D.C.R.H=Drying Cabinet Relative Humidity

\section{Results on $2^{\text {nd }}$ October 2015}

Table 7: Variation of relative humidity with time on the second day

\begin{tabular}{|c|c|c|c|c|c|c|c|c|c|}
\hline Day 2 & \multicolumn{10}{|c|}{} \\
\hline Time & $\mathbf{9}$ & $\mathbf{1 0}$ & $\mathbf{1 1}$ & $\mathbf{1 2}$ & $\mathbf{1 3}$ & $\mathbf{1 4}$ & $\mathbf{1 5}$ & $\mathbf{1 6}$ & $\mathbf{1 7}$ \\
\hline A.R.H & 65 & 62 & 60 & 59 & 58 & 59 & 59 & 58 & 58 \\
\hline C.R.H & 30 & 27 & 25 & 24 & 23 & 24 & 24 & 23 & 23 \\
\hline D.C.R.H & 38 & 35 & 33 & 32 & 31 & 32 & 32 & 31 & 31 \\
\hline
\end{tabular}

Results on $3^{\text {rd }}$ October 2015

Table 8: Variation of relative humidity with time on the third day

\begin{tabular}{|c|c|c|c|c|c|c|c|c|c|}
\hline Day 3 & \multicolumn{10}{|c|}{$\mathbf{1 0}$} & $\mathbf{1 0}$ & $\mathbf{1 4}$ & $\mathbf{1 7}$ \\
\hline Time & $\mathbf{9}$ & $\mathbf{1 0}$ & $\mathbf{1 1}$ & $\mathbf{1 2}$ & $\mathbf{1 3}$ & $\mathbf{1 4}$ & $\mathbf{1 5}$ & $\mathbf{1 6}$ & $\mathbf{1 7}$ \\
\hline A.R.H & 62 & 60 & 58 & 58 & 57 & 56 & 57 & 58 & 60 \\
\hline C.R.H & 27 & 25 & 23 & 23 & 22 & 21 & 22 & 23 & 25 \\
\hline D.C.R.H & 35 & 33 & 31 & 31 & 30 & 29 & 30 & 31 & 33 \\
\hline
\end{tabular}

Results on $4^{\text {th }}$ October 2015

Table 9: Variation of Relative Humidity with

Time on the Fourth day

\begin{tabular}{|c|c|c|c|c|c|c|c|c|c|}
\hline Day 4 & \multicolumn{10}{|c|}{} \\
\hline Time & $\mathbf{9}$ & $\mathbf{1 0}$ & $\mathbf{1 1}$ & $\mathbf{1 2}$ & $\mathbf{1 3}$ & $\mathbf{1 4}$ & $\mathbf{1 5}$ & $\mathbf{1 6}$ & $\mathbf{1 7}$ \\
\hline A.R.H & 63 & 62 & 59 & 58 & 61 & 63 & 63 & 64 & 67 \\
\hline C.R.H & 28 & 27 & 24 & 23 & 26 & 28 & 28 & 29 & 32 \\
\hline D.C.R.H & 36 & 35 & 32 & 31 & 34 & 36 & 36 & 37 & 40 \\
\hline
\end{tabular}

Results on $5^{\text {th }}$ October 2015

Table 10: Variation of relative humidity with time on the fifth day

\begin{tabular}{|c|c|c|c|c|c|c|c|c|c|}
\hline Day 5 & \multicolumn{10}{|c|}{$\mathbf{1 0}$} \\
\hline Time & $\mathbf{9}$ & $\mathbf{1 0}$ & $\mathbf{1 1}$ & $\mathbf{1 2}$ & $\mathbf{1 3}$ & $\mathbf{1 4}$ & $\mathbf{1 5}$ & $\mathbf{1 6}$ & $\mathbf{1 7}$ \\
\hline A.R.H & 65 & 66 & 65 & 62 & 62 & 63 & 63 & 64 & 67 \\
\hline C.R.H & 30 & 31 & 30 & 27 & 27 & 28 & 28 & 29 & 32 \\
\hline D.C.R.H & 38 & 39 & 38 & 35 & 35 & 36 & 36 & 37 & 40 \\
\hline
\end{tabular}

Figures $4.1-4.5$ show a typical da y results of the hourly variation of the relative humidities in the solar collector and the drying cabinet $\mathrm{c}$ ompared to the ambient temperature. The results show that the drying processes were enhanced by the heated air at very low humidity.

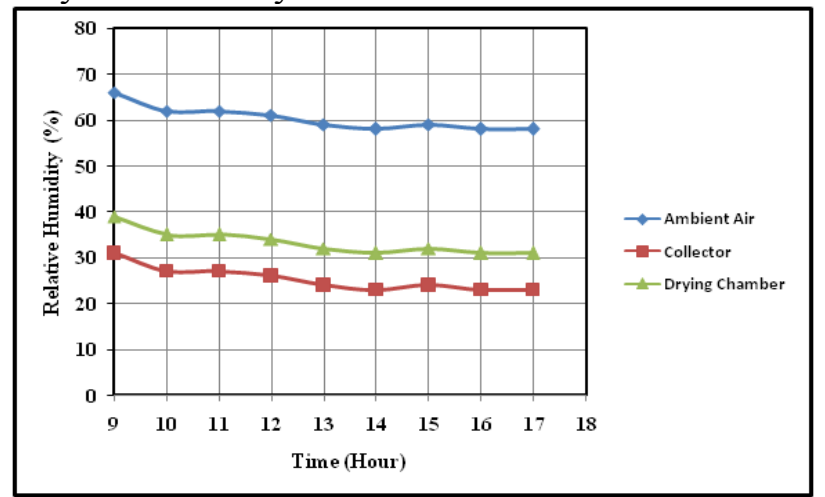

Fig. 4.1 Variation of air humidity with time on the first day

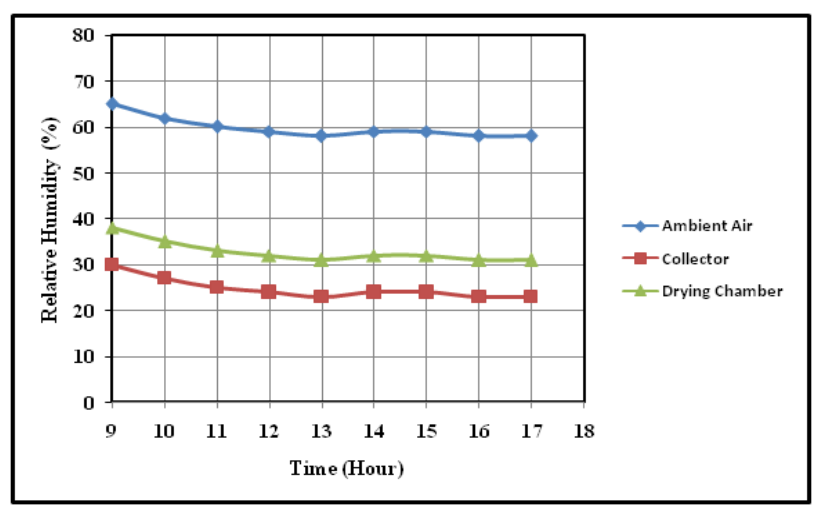

Fig. 4.2 Variation of air humidity with time on the second day

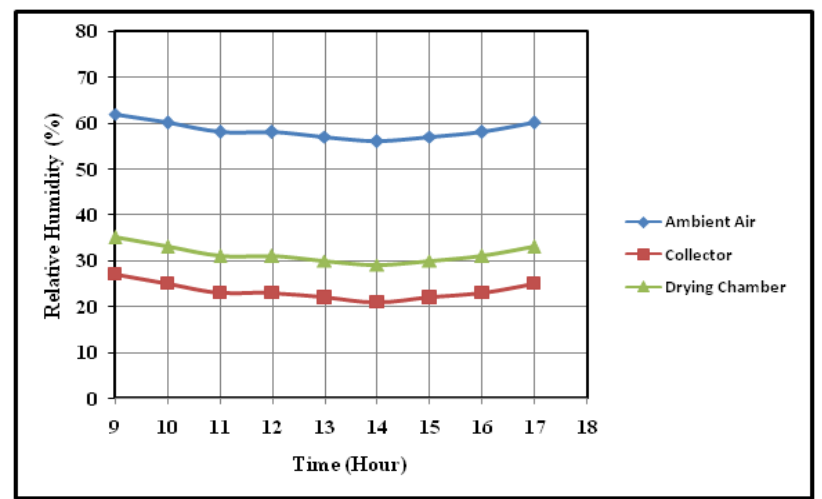

Fig. 4.3 Variation of air humidity with time on the third day 


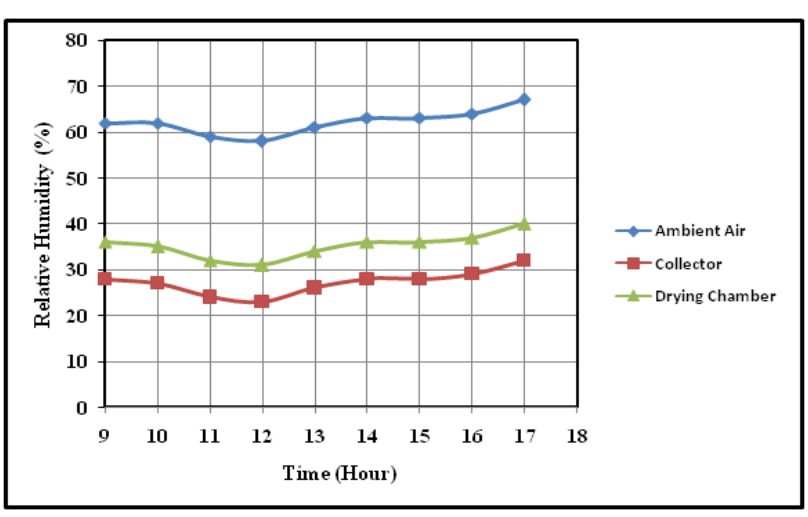

Fig. 4.4 Variation of air humidity with time on the fourth day

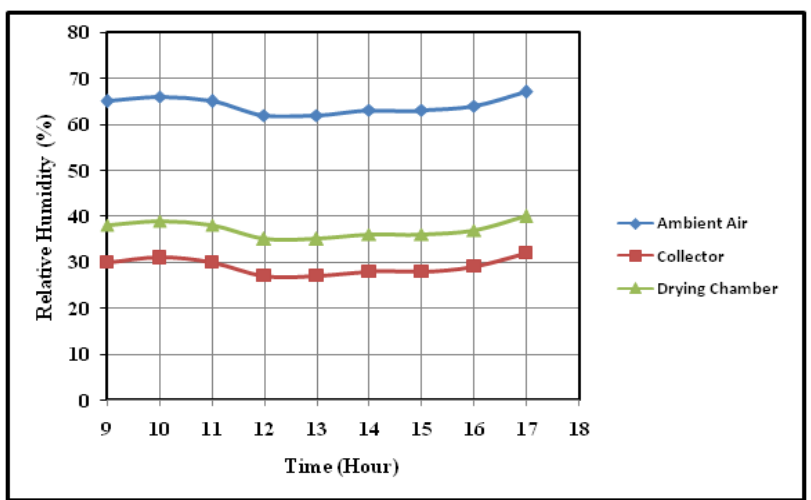

Fig. 4.5 Variation of air humidity with time on the fifth day

\subsection{Variation of mass of the potato and moisture loss with time}

Tables $11-15$ and Fig ures $5.1-5.5$ show the variation of mass of the $p$ otato and moisture loss in the mixed-mode solar foo $d$ dryer. It was observed that the dry ing rate incre ased due to increase in temperature between $12.00 \mathrm{~h}$ and $14.00 \mathrm{~h}$ but decreased thereafter, which shows the earlier and faster removal of moisture from the dried item. Also It was observed from tables $11-15$ that the moisture removed and total $\mathrm{m}$ oisture loss in first day was greater than all day s after, this happene $d$ as a result of an increase in moisture content on the first day from the following da ys, and then the moisture content begins to decrease gradually after that. It was observed that the moisture removed from first day was $419 \mathrm{~g}$ and the tot al moisture loss was 24.9 $\%$. In the s econd day it was observed that the moisture removed was $257 \mathrm{~g}$ and the total moisture loss was $20.4 \%$. In the $t$ hird day it $w$ as observed that the moisture removed was $191 \mathrm{~g}$ and the total moisture loss was $19 \%$. In the fourth day it was observed that the moisture removed was $136 \mathrm{~g}$ and the total moisture loss was $16.7 \%$. In the fifth day it was observed that the m oisture removed was $108 \mathrm{~g}$ and the total moisture loss was $15.9 \%$.

\section{Results on $1^{\text {st }}$ October 2015}

Table11: Variation of mass of the potato and moisture loss with time on the first day

\begin{tabular}{|c|c|c|c|c|c|c|c|c|c|}
\hline $\begin{array}{c}\text { Day } \\
1\end{array}$ & \multicolumn{9}{|c|}{$\begin{array}{c}\text { Moisture removed }=1680-1261=419 \mathrm{~g} \\
\text { Total moisture loss }=24.9 \%\end{array}$} \\
\hline Tim & 9 & 10 & 11 & 12 & 13 & 14 & 15 & 16 & 17 \\
\hline Mas & 16 & 16 & 16 & 15 & 15 & 14 & 13 & 13 & 12 \\
\hline$s$ (g) & 80 & 61 & 24 & 69 & 03 & 29 & 62 & 04 & 61 \\
\hline $\begin{array}{l}\text { M.L } \\
.(g)\end{array}$ & - & 19 & 37 & 55 & 66 & 74 & 67 & 58 & 43 \\
\hline $\begin{array}{l}\% \\
\text { M.L }\end{array}$ & - & 1.1 & 2.2 & 3.3 & 3.9 & 4.4 & 4 & 3.5 & 2.5 \\
\hline
\end{tabular}

\section{Results on $2^{\text {nd }}$ October 2015}

Table 12: Variation of mass of the potato and moisture loss with time on the second day

\begin{tabular}{|c|c|c|c|c|c|c|c|c|c|}
\hline $\begin{array}{c}\text { Day } \\
\mathbf{2}\end{array}$ & \multicolumn{7}{|c|}{ Moisture removed $=\mathbf{1 2 6 1}-\mathbf{1 0 0 4}=\mathbf{2 5 7} \mathbf{g}$} \\
\hline $\begin{array}{c}\text { Tim } \\
\text { e }\end{array}$ & $\mathbf{9}$ & $\mathbf{1 0}$ & $\mathbf{1 1}$ & $\mathbf{1 2}$ & $\mathbf{1 3}$ & $\mathbf{1 4}$ & $\mathbf{1 5}$ & $\mathbf{1 6}$ & $\mathbf{1 7}$ \\
\hline $\begin{array}{c}\text { Mas } \\
\text { s (g) }\end{array}$ & 12 & 12 & 12 & 12 & 11 & 11 & 10 & 10 & 10 \\
\hline $\begin{array}{c}\text { M.L } \\
\text {.g) }\end{array}$ & - & 9 & 35 & 10 & 66 & 12 & 65 & 27 & 04 \\
\hline $\begin{array}{c}\text { \% } \\
\text { M.L }\end{array}$ & - & 0.7 & 1.3 & 2 & 3.5 & 4.3 & 3.7 & 31 & .8 \\
\hline
\end{tabular}

\section{Results on $3^{\text {rd }}$ October 2015}

Table 13: Variation of mass of the potato and moisture loss with time on the third day

\begin{tabular}{|c|c|c|c|c|c|c|c|c|c|}
\hline Day 3 & \multicolumn{7}{|c|}{ Moisture removed = 1004 - 813 = 191 g } \\
\hline Time & $\mathbf{9}$ & $\mathbf{1 0}$ & $\mathbf{1 1}$ & $\mathbf{1 2}$ & $\mathbf{1 3}$ & $\mathbf{1 4}$ & $\mathbf{1 5}$ & $\mathbf{1 6}$ & $\mathbf{1 7}$ \\
\hline $\begin{array}{c}\text { Mass } \\
\text { (g) }\end{array}$ & 10 & 99 & 98 & 96 & 93 & 88 & 85 & 82 & 81 \\
\hline $\begin{array}{c}\text { M.L. } \\
\text { (g) }\end{array}$ & - & 7 & 5 & 3 & 0 & 4 & 0 & 8 & 3 \\
\hline $\begin{array}{c}\text { \% } \\
\text { M.L }\end{array}$ & - & 0.7 & 12 & 22 & 33 & 46 & 34 & 22 & 15 \\
\hline
\end{tabular}

\section{Results on $4^{\text {th }}$ October 2015}

Table 14: Variation of mass of the potato and moisture loss with time on the fourth day

\begin{tabular}{|c|c|c|c|c|c|c|c|c|c|}
\hline $\begin{array}{c}\text { Day } \\
\mathbf{4}\end{array}$ & \multicolumn{7}{|c|}{ Moisture removed = 813 - 677 = 136 g } \\
\hline Time & $\mathbf{9}$ & $\mathbf{1 0}$ & $\mathbf{1 1}$ & $\mathbf{1 2}$ & $\mathbf{1 3}$ & $\mathbf{1 4}$ & $\mathbf{1 5}$ & $\mathbf{1 6}$ & $\mathbf{1 7}$ \\
\hline $\begin{array}{c}\text { Mass } \\
\text { (g) }\end{array}$ & 31 & 80 & 80 & 78 & 76 & 73 & 70 & 69 & 67 \\
\hline $\begin{array}{c}\text { M.L. } \\
\text { (g) }\end{array}$ & - & 5 & 8 & 16 & 22 & 32 & 24 & 16 & 13 \\
\hline $\begin{array}{c}\text { \% } \\
\text { M.L }\end{array}$ & - & 0. & 1 & 2 & 2.7 & 3.9 & 2.9 & 2 & 1.6 \\
\hline
\end{tabular}


Results on $5^{\text {th }}$ October 2015

Table 15: Variation of mass of the potato and moisture loss with time on the fifth day

\begin{tabular}{|c|c|c|c|c|c|c|c|c|c|}
\hline $\begin{array}{c}\text { Day } \\
\mathbf{5}\end{array}$ & \multicolumn{7}{|c|}{ Moisture removed $=\mathbf{6 7 7}-\mathbf{5 6 9}=\mathbf{1 0 8} \mathbf{~ g}$} \\
\hline Time & $\mathbf{9}$ & $\mathbf{1 0}$ & $\mathbf{1 1}$ & $\mathbf{1 2}$ & $\mathbf{1 3}$ & $\mathbf{1 4}$ & $\mathbf{1 5}$ & $\mathbf{1 6}$ & $\mathbf{1 7}$ \\
\hline $\begin{array}{c}\text { Mass } \\
\text { (g) }\end{array}$ & $\begin{array}{c}6 \\
7\end{array}$ & $\begin{array}{c}67 \\
7\end{array}$ & $\begin{array}{c}66 \\
7\end{array}$ & $\begin{array}{c}65 \\
5\end{array}$ & $\begin{array}{c}63 \\
9\end{array}$ & $\begin{array}{c}61 \\
3\end{array}$ & $\begin{array}{c}59 \\
4\end{array}$ & $\begin{array}{c}58 \\
0\end{array}$ & $\begin{array}{c}56 \\
9\end{array}$ \\
\hline $\begin{array}{c}\text { M.L. } \\
\text { (g) }\end{array}$ & - & 4 & 6 & 12 & 16 & 26 & 19 & 14 & 11 \\
\hline $\begin{array}{c}\text { \% } \\
\text { M.L }\end{array}$ & - & 0.6 & 0.9 & 1.8 & 2.3 & 3.8 & 2.8 & 2.1 & 1.6 \\
\hline
\end{tabular}

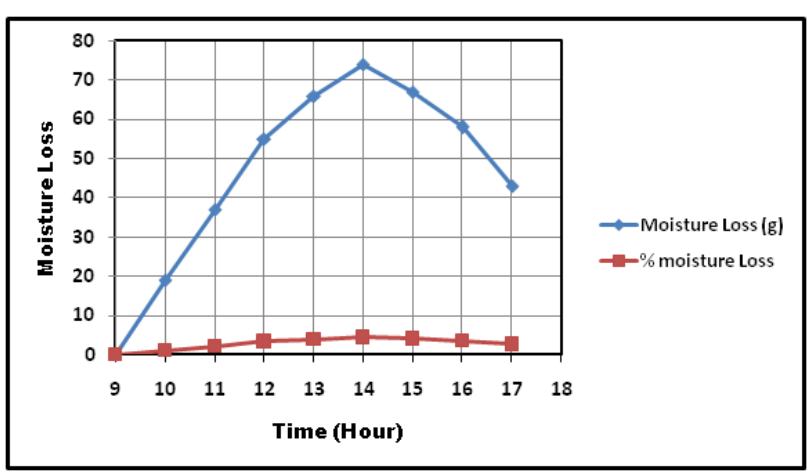

Fig. 5.1 Variation of moisture loss with time on the first day

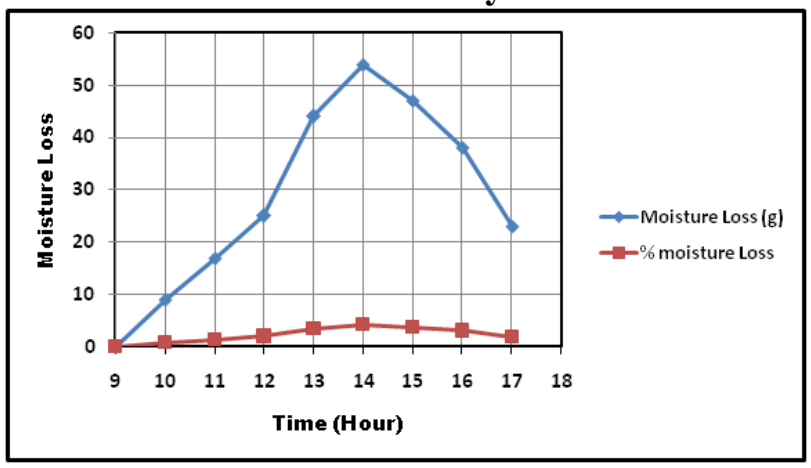

Fig. 5.2 Variation of moisture loss with time on the second day

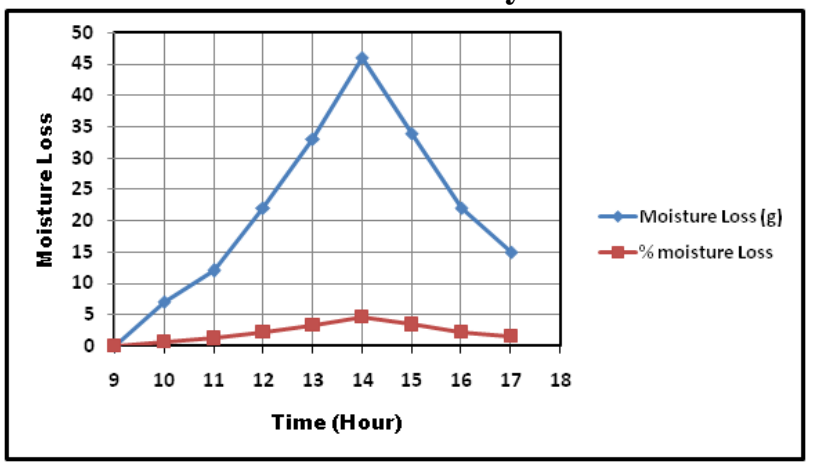

Fig. 5.3 Variation of moisture loss with time on the third day

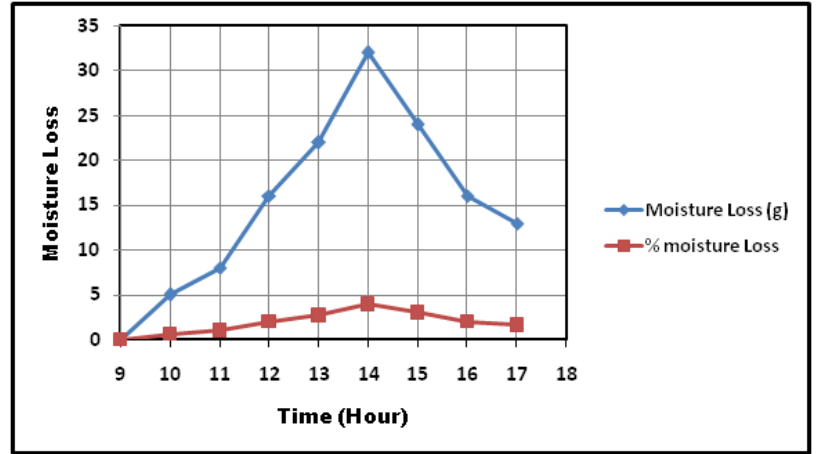

Fig. 5.4 Variation of moisture loss with time on the fourth day

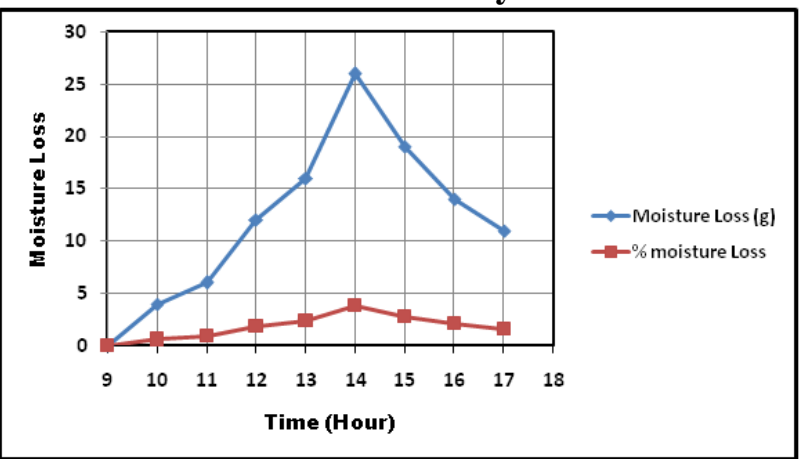

Fig. 5.5 Variation of moisture loss with time on the fifth day

Based on the results obtained during the test, temperature above $65{ }^{\circ} \mathrm{C}$ was recorded inside the drying cabinet. This high te mperature in the drying cabinet causes $419 \mathrm{~g}$ of moisture to be removed on the first day, $257 \mathrm{~g}$ on the second day, $191 \mathrm{~g}$ on the third day, $136 \mathrm{~g}$ on the fourth day and finally $108 \mathrm{~g}$ on the fifth day. At the end of the five day $s$ of drying process, the mass of $1680 \mathrm{~g}$ of potato was reduced to $569 \mathrm{~g}$. Total amount of $\mathrm{m}$ oisture removed was $1111 \mathrm{~g}$ and total $\mathrm{m}$ oisture loss was $66.1 \%$, which is the required am ount of moisture to be removed for safe drying of freshly potato slides.

Variations in $\mathrm{m}$ oisture removed and moisture content were observed as sh own in Table 16 and Figures $6 \& 7$.

Table 16: Variation of moisture removed and moisture loss with time for the drying 5 days

\begin{tabular}{|c|c|c|}
\hline Day & $\begin{array}{c}\text { Moisture removed } \\
\text { (g) }\end{array}$ & $\begin{array}{c}\text { Total moisture } \\
\text { loss (\%) }\end{array}$ \\
\hline 1 & 419 & 24.9 \\
\hline 2 & 257 & 20.4 \\
\hline 3 & 191 & 19 \\
\hline 4 & 136 & 16.7 \\
\hline 5 & 108 & 15.9 \\
\hline
\end{tabular}




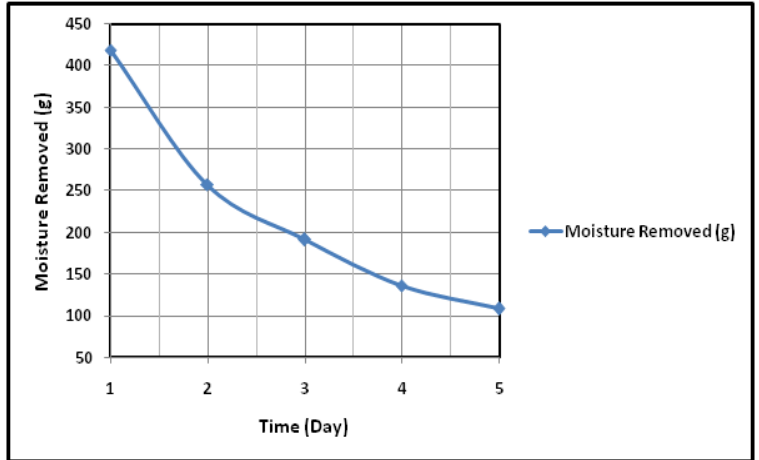

Fig. 6 Variation of moisture removed with time through 5 days

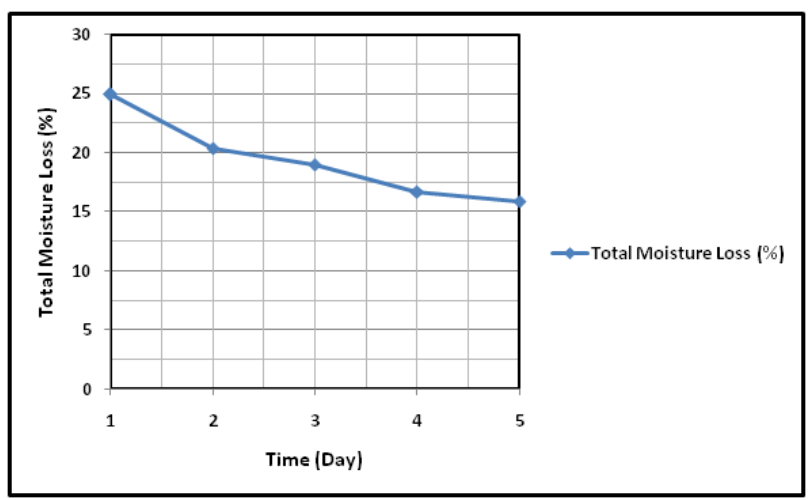

Fig. 7 Variation of total moisture loss with time through 5 days

The moisture content of the freshly potato slides was $24.9 \%$ at the end of drying for the first day at about 5:00 pm, $20.4 \%$ at the end of dry ing for the second day, $19 \%$ at the end of dr ying for the third day, $16.7 \%$ at the end of drying for the fourth day and finally $15.9 \%$ at the end of dr ying for the fifth day. It was observed that the dry ing rate increased from the end of one day to another, which shows the earlier and faster removal of moisture from the dried item.

\section{Conclusions}

- The temperatures inside the dryer cabinet and the solar collector are much higher than the a mbient temperature during most hours of the daylight. The temperature inside the solar collector was up to $27{ }^{\circ} \mathrm{C}$ approximately higher than the ambient temperature. The temperature inside the dry ing cabinet was up to $22{ }^{\circ} \mathrm{C}$ approximately higher than the a mbient temperature for ab out three hours immediately after $12.00 \mathrm{~h}$ (noon).

- The relative humidity in the solar collector and drying cabinet were low er than the am bient air relative humidity, with the ambient air recording the highest relative humidity at each reading followed by the drying cabinet and finally by the solar collector. Because of the decrease $d$ relative humidity inside the dryer, all the $t$ ime, the temperature inside the dr yer was high which is sufficient enough to dry the potato at an early time.

- Based on th e results obtained during the te st, temperature above $65{ }^{\circ} \mathrm{C}$ was recorded inside the drying cabinet. This high tem perature in the drying cabinet causes $419 \mathrm{~g}$ of $\mathrm{m}$ oisture to be removed on the first day, $257 \mathrm{~g}$ on the second day, $191 \mathrm{~g}$ on the third day, $136 \mathrm{~g}$ on the fourth day and finally $108 \mathrm{~g}$ on the fifth day. At the end of the five day s of dry ing process, the mass of $1680 \mathrm{~g}$ of $\mathrm{p}$ otato was reduced to $569 \mathrm{~g}$. Total amount of moisture removed was $1111 \mathrm{~g}$ an d total moisture loss was $66.1 \%$, which is the required amount of moisture to be rem oved for safe drying of freshly potato slides.

- The moisture content of the freshly potato slides was $24.9 \%$ at the end of $d$ rying for the first day at about 5:00 pm, $20.4 \%$ at the end of drying for the second day, $19 \%$ at the end of drying for the third day, $16.7 \%$ at the end of drying for the fourth day and finally $15.9 \%$ at the end of drying for the fifth day. It was observed that the dry ing rate increased from the end of on $e$ day to another, which shows t he earlier and faster removal of moisture from the dried item.

\section{References:}

[1] Akoy E, Ismail M, El-Fadil AA: Design and construction of a solar dryer for mango slices. In: Proceedings of International Research on Food Security, Natural Resource Management and Rural Development-Tropentag. Bonn, Germany: University of Bonn; 2006.

[2] Bolaji BO, Olalusi AP: Performance ev aluation of a mixed-mode solar dryer, AU Journal of Technology, a Publication of Assum ption University, Bangkok. Thailand 2008, 11(4):225-231.

[3] Bolaji BO: Performance evaluation of a simple solar dryer for food preservation. In: Proceedings of the 6th Annual Engineering Conference of School of Engineering and Technology. Minna, Nigeria: Federal University of Technology; 2005.

[4] Tripathy PP, Kumar S: Modeling of heat transfer and energy analysis of potato slices and cylinders during solar dry ing. Applied Thermal Eng. 2009, 29: 884-891. 10.1016/j.applthermaleng.2008.04.018

[5] Ramana Murthy MV: A review of new technologies, models and ex perimental investigations of solar dri ers. Renewable and 
Sustainable Energy Reviews. 2009, 13(4):835844. 10.1016/j.rser.2008.02.010

[6] Karim MA, Hawlader MNA: Drying characteristics of banana: theoretical modelling and experimental validation. J. Food Eng. 2005, 70: 35-45. 10.1016/j.jfoodeng.2004.09.010

[7] Smitabhindu R, Janjai S, Chankong V:

Optimization of a solar-assisted drying system for drying bananas. Renew. Energy 2008, 33: 1523-1531. 10.1016/j.renene.2007.09.021

[8] Togrul, I.T.; and Pehlivan, D. 2004. Modelling of thin layer drying kinetics of some fruits under open-air sun drying process. J. Food Engin. 65: 413-25.

[9] Bolaji, B.O. 2005. Performance evaluation of a simple solar dryer for food preservation. Proc. 6th Ann. Engin. Conf. of Sch ool of Engineering and Engi neering Technology, Minna, Nigeria, pp. 8-13.

[10] Koyuncu, T., 2006. Performance of various designs of solar air heaters for drying applications. Renewable Energy, Vol.31, p p. 1073-1088.

[11] Shanmugam, V., Natarajan, E., 2006.

Experimental investigation of forced convection and desiccant integrated solar dryer. Renewable Energy, Vol.31, pp. 12391251.

[12] Waewsak, J.; Chindaruksa, S.; and Punlek, C. 2006. A mathematical modelling study of hot air drying for some agricultural products. Thammasat Int. J. Sci. Technol. 11(1): 14-20.

[13] Murthy, R. 2009. A review of new technologies, models and experimental investigations of solar dryers. Renewable and Sustainable Energy Reviews, Vol.13, pp. 835-844.

[14] Sharma, A., Chen, C. R., Vu Lan, N., 2009. Solar- energy drying systems: A review. Renewable and Sustainable Energy Reviews, Vol.13, pp. 1185-1210.

[15] M. Mohandes and S. Rehman, 2010. Global Solar Radiation Maps of Saudi Arabia. Journal of Energy and Power Engineering, ISSN 19348975, USA, December 2010, Volume 4, No.12 (Serial No.37). 